\title{
Corporate Governance Mechanisms, Whistle-Blowing Policy and Real Earnings Management
}

\author{
Mujeeb Saif Mohsen Al-Absy ${ }^{1}, \mathrm{Ku}$ Nor Izah Ku Ismail ${ }^{1} \&$ Sitraselvi Chandren $^{1}$ \\ ${ }^{1}$ Tunku Puteri Intan Safinaz School of Accounting, University Utara Malaysia, Malaysia \\ Correspondence: Mujeeb Saif Mohsen Al-Absy, Tunku Puteri Intan Safinaz School of Accounting, University Utara \\ Malaysia, Malaysia. Tel: 60-111-544-8099.
}

Received: June 10, 2019

Accepted: September 14, 2019

Online Published: September 17, 2019

doi:10.5430/ijfr.v10n6p265

URL: https://doi.org/10.5430/ijfr.v10n6p265

\begin{abstract}
The purpose of this study is to investigate whether the mechanisms of corporate governance (CG) in firms that have a policy of whistle-blowing (WBP) are more effective in mitigating real earnings management (REM) than those without WBP. To achieve this objective, a sample of 288 Malaysian firms for the years 2013 to 2015, have been grouped into firms with and without WBP. In addition, the Roychowdhury Models were used to determine the abnormal levels of the REM. The results show that most of the CG mechanisms, i.e., audit committee (AC) size, AC meetings, AC independence and auditor size in firms with WBP are found to be significantly associated with low level of REM, supporting agency and resource dependence theories. However, only board independence and ownership concentration are found to be significantly associated with high level of REM. Regarding firms without WBP, most of the CG mechanisms, i.e., AC size, women in the $\mathrm{AC}$, AC accounting expertise and ownership concentration, are found to be significantly associated with a high level of REM. However, only board meetings, AC multiple directorships and auditor size are found to be significantly associated with low level of REM. The findings of this study suggest that having WBP in a firm could improve the monitoring role of the CG mechanisms towards mitigating REM. However, strengthening the role of WBP is still necessary to improve the efficiency of the monitoring role of CG mechanisms. Hence, there is a need for more policies that could encourage whistle-blowers to disclose any misconducts in firms and at the same time, prevent management from undermining the effectiveness of the whistle-blowing policy. The findings of this study will enrich the body of literature due to the absence of studies that examine the influence of WBP on REM.
\end{abstract}

Keywords: corporate governance, real earnings management, whistle-blowing policy, Malaysia

\section{Introduction}

Management has the responsibility to produce a reliable and accurate financial report for stakeholders. However, when managers fail to fulfil their obligations, they practice earnings management (EM) by exploiting the flexibility of the accounting principles or daily operational activities. This act may hide the firm's actual financial condition, thereby delaying its collapse (Jones, 2011). Subsequently, it will force the management to indulge in reporting inaccurate accounting information or engaging in fraud (Abdul-Rahman \& Ali, 2006; Jones, 2011; Kazemian \& Sanusi, 2015). Previous studies provided evidence that managing earnings would result in fraud practices (Hasnan, Abdul-Rahman, \& Mahenthiran, 2013; Perols \& Lougee, 2011; Sulaiman, Danbatta, \& Rahman, 2014). The issue of managing earnings continues to be a prevalent topic in the field of accounting (Ayedh, Fatima, \& Mohammad, 2019; Chandren, 2016; Chandren, Ahmad, \& Ali, 2017; Inaam \& Khamoussi, 2016; Jones, Krishnan, \& Melendrez, 2008; Soliman \& Ragab, 2014; Teh, San Ong, \& Ying, 2017; Vladu, 2015; Xu \& Ji, 2016), where it needs to be studied further, particularly in Malaysia (Ahmed, 2017; Buniamin, Johari, Rahman, \& Rauf, 2012; Hamid, Hashim, \& Salleh, 2012; Nia, Huang, \& Abidin, 2015; Teh et al., 2017). Furthermore, various measures could be implemented to limit EM practice (Alves, 2012; Kazemian \& Sanusi, 2015); governments should develop stricter security laws and regulations for publicly traded companies to prevent EM practices (Liu \& Wang, 2017).

According to agency theory and previous studies, the mechanisms of corporate governance (CG), e.g., board of directors (BOD), audit committee (AC), ownership structure and internal and external control, could reduce agency problems and EM practices (Fama \& Jensen, 1983; Jensen \& Meckling, 1976; Klein, 2002). However, in Asian countries, researchers have argued that CG mechanisms are not efficient in mitigate agency problems (Cheung \& 
Chan, 2004; Claessens \& Fan, 2002). Further, Nam and Nam (2004) stated that the main reason for the 1997 Asian Financial Crisis was the weakness of CG. In the context of Malaysia, the swift economic meltdown of Malaysia in the midst of 1997 uncovered the effects of poor CG (Abdul-Rahman \& Ali, 2006; Ow-Yong \& Kooi-Guan, 2000). Hence, this situation has resulted in significant efforts by the Malaysian government to improve the efficiency of CG (Hassan, Moyes, Mohd-Sanusi, \& Iskandar, 2010; Rachagan \& Kuppusamy, 2013; Zainal Abidin \& Ahmad, 2007), starting with the establishment of a strong Finance Committee on Corporate Governance (FCCG) in 1999 (Zainal Abidin \& Ahmad, 2007) for reviewing and reforming Malaysia's CG, and the revision of the Malaysian Code of Corporate Governance (MCCG) in 2000, 2007, 2012 and finally in 2017. This indicates that the mechanisms of CG in Malaysian firms are insufficient in preventing EM. Thus, there is a need to improve CG (Mohammad, Wasiuzzaman, \& Salleh, 2016).

The aim of this study is to investigate whether the mechanisms of CG in firms that have a policy of whistle-blowing (WBP) are more effective in mitigating real earnings management (REM) than those without WBP. This study proposes that functional and effective governance can be attained by having a WBP, which may significantly reduce EM activities. The establishing of a policy such as WBP in a firm could enhance the flow of the firm's information to directors, who in many cases have full-time jobs in other corporations. Further, WBP could create a diversity of sources of data acquisition regarding the relevant firm-specific information instead of relying on the chief executive officer (CEO). Moreover, it encourages firms' accountants, auditors and external auditors to report the wrongdoings sooner. Thus, the existence of WBP could improve the monitoring role of CG mechanisms (Alam, 2009; Bowen, Call, \& Rajgopal, 2010; Friebel \& Guriev, 2012; Mak, 2007; Meng \& Fook, 2011; Packin \& Edwards, 2016; Schultz \& Harutyunyan, 2015). Many CG codes, including the MCCG, have required firms to formulate the WBP. Thus, studies on whistle-blowing policies are very much needed to guide the regulators and firms, especially in Malaysia, to establish a suitable policy that can encourage employees to expose unethical behaviour within their organization (Ahmad, Ismail, \& Azmi, 2013). Moreover, Shawver and Shawver (2007) called for future research to examine practicing accountants' beliefs regarding whistle-blowing policy in EM situations.

Upon reviewing previous studies, there is only one study that has examined the influence of CG mechanism in firms with WBP on mitigating the accrual earnings management (AEM), as a common proxy of EM (Al-Absy, Ku Ismail, \& Chandren, 2019a). However, none has examined that relationship with REM, as the latest proxy of EM. REM is a new issue (Sun, Lan, \& Liu, 2014), which has not been adequately addressed by most regulators (Francis, Hasan, \& $\mathrm{Li}, 2016$ ), and not been much investigated in Malaysia (Kalgo, Noordin, Nahar, \& Turmin, 2015). It has been argued that managers have turned away from AEM to REM (Nia, Sinnadurai, Sanusi, \& Hermawan, 2017), particularly following the implementation of the International Financial Reporting Standards (IFRSs) (Khoo \& Ahmad-Zaluki, 2015; Wan Ismail, Kamarudin, Zijl, \& Dunstan, 2013) introduced by the International Accounting Standards Board (Al-Absy \& Ku Ismail, 2019; Al-Absy, Ku Ismail, \& Al-Dubai, 2016). Like in many other countries, some evidence on REM in Malaysia has been documented. Enomoto, Kimura, and Yamaguchi (2015) found that the aggregate score of REM in Malaysia is the 6th highest among 38 countries (33.5). Further, Francis et al. (2016) found that the mean values of abnormal discretionary expenses and abnormal production costs of Malaysian firms are 0.024 and 0.048, (ranked $28^{\text {th }}$ and $29^{\text {th }}$ among 38 countries), respectively. Likewise, Lemma, Negash, Mlilo, and Lulseged (2018) found that the mean of REM in Malaysia is 0.502 , which is the $30^{\text {st }}$ highest among 41 countries. Therefore, this study contributes to the body of knowledge by extending the previous study by Al-Absy et al. (2019a) and focusing on REM instead of AEM. This study would assist policymakers and stakeholders in improving the role of CG by highlighting the importance of having a WBP in a firm.

\section{Literature Review}

Managers, as agents, will not always act in the best interests of the principals (shareholders). Isolating the principals from managing a company's activities and delegating this task to management may motivate managers to behave opportunistically for their own benefit. This situation leads principals to look for some mechanisms that can allow them to control the agent's decisions better, thereby preventing the agent from making decisions that may affect the principal's interests. The agency theory introduced by Fama and Jensen (1983) provides theoretical support for the implementation of CG mechanisms in EM related studies. Besides agency theory, the resource dependence theory plays an essential role in improving firm governance and managers' directions. The resource dependence theory asserts that firms should obtain vital resources from the environment (Salancik \& Pfeffer, 1978). Based on this theory, the BOD can increase firm value, i.e., by accessing resources and information (Boyd, 1990); linking firms to their stakeholders (Lückerath-Rovers, 2009); and providing experience and knowledge (Hillman, Cannella, \& Paetzold, 2000). 
Consequently, previous studies have extensively examined the influence of BOD mechanisms, i.e., CEO chairmanship (Abdul-Rahman \& Ali, 2006; Saleh, Iskandar, \& Rahmat, 2005) chairman independence (Al-Zyoud, 2012; Habbash, 2011; Mohammad et al., 2016), board independence (Chandren, Ahmad, \& Ali, 2015; Ku Ismail \& Abdullah, 2013; Mansor, Che-Ahmad, Ahmad-Zaluki, \& Osman, 2013), board size (Abdullah \& Ku Ismail, 2016; Mohammad et al., 2016; Zalata, Tauringana, \& Tingbani, 2018), board meetings (Ahmed, 2017; Mansor et al., 2013; Mohammad et al., 2016), women on the boards (Abdullah \& Ku Ismail, 2012, 2016; Buniamin et al., 2012; Ku Ismail \& Abdullah, 2013), board directors with corporate background and experience (Ahmed, 2017; Buniamin et al., 2012; Xie, Davidson, \& DaDalt, 2003) and board directors with multiple directorships (Baccouche \& Omri, 2014; Chandren et al., 2015; Jamaludin, Sanusi, \& Kamaluddin, 2015) on mitigating the level of EM. Further, other studies also have extensively examined the influence of AC mechanisms, i.e., AC size (Abdullah \& Ku Ismail, 2016; Al-Rassas \& Kamardin, 2015; Mansor et al., 2013), AC meeting (Abdul-Rahman \& Ali, 2006; Al-Rassas \& Kamardin, 2015; Ishak, Haron, Salleh, \& Rashid, 2011), AC independence (Abdul-Rahman \& Ali, 2006; Al-Rassas \& Kamardin, 2016; Haji-Abdullah \& Wan-Hussin, 2015), women in the AC (Ku Ismail \& Abdullah, 2013; Salleh \& Haat, 2013), AC accounting expertise (Al-Rassas \& Kamardin, 2016; Mohammad et al., 2016; Zalata et al., 2018), and AC multiple directorships (Baccouche, Hadriche, \& Omri, 2013; Jamaludin et al., 2015; Yang \& Krishnan, 2005) on mitigating the level of EM.

However, the results of above-mentioned studies are inconsistent. Furthermore, previous studies did not provide definitive conclusions regarding the effectiveness of BOD in mitigating EM (Baccouche \& Omri, 2014), particularly in Malaysia where there is a need for improving the role of CG in mitigating the level of EM (Mohammad et al., 2016). Likewise, previous studies have not established a definitive relationship between the AC mechanisms and EM. In the context of Malaysia, ACs have yet to achieve massive success in their monitoring duty (Abdul-Rahman \& Ali, 2006). Although the majority of firms have implemented the MCCG, ACs have not been effective in constraining EM (Chandrasegaram, Rahimansa, Rahman, Abdullah, \& Mat, 2013). Thus, more studies are recommended (Al-Rassas \& Kamardin, 2016; Chandrasegaram et al., 2013; Inaam \& Khamoussi, 2016).

The revised Code of $\mathrm{CG}$ in Malaysia has continually attempted to improve the role of CG mechanisms, namely the BOD and its committees. Indeed, the independence of the BOD is the primary concern of the MCCG. The MCCG 2000 and 2007 required at least one third of the board to be independent directors; the MCCG 2012 required a majority of directors to be independent in the case where the board chairman is not an independent director, and currently, the MCCG 2017 requires at least half of the board to be independent; however, in large companies, it requires a majority of directors to be independent. Furthermore, other concerns have also been highlighted in the revised codes, such as the separate roles of the chairman and the CEO. The MCCG 2001 and 2007 required the position of the CEO and Board Chairman to be held by a different person. Otherwise, the board should explain the reasons for one person occupying both positions. The MCCG 2012 did not allow this combination; it also required the chairman to be a non-executive director. Currently, the MCCG 2017 has an additional requirement, in which the chairman of the $\mathrm{AC}$ has to be a different person from the board chairman. This is to enhance the objectivity of the board in reviewing the AC's findings and recommendations. More policies have also been introduced by the MCCG to strengthen and balance the board composition. The Malaysian Government policy stipulates that $30 \%$ of the board must be women by 2016 (currently revised to 2020). Importantly, to ensure the compliance of listed companies with this policy, the MCCG 2012 required the board to establish and disclose its gender diversity policy and how this target will be achieved. The MCCG 2017 is mandating large companies to have at least $30 \%$ of women directors.

In terms of the board committees, the board is required to establish an AC of at least three directors. In terms of the independent directors in the AC, the MCCG 2000 required a majority of directors to be independent, the chairman inclusive. This requirement was modified in MCCG 2007, whereby all members of the AC must be non-executive and financially literate, with at least one member as a member of an accounting association or body. The MCCG 2017 has an additional modification which encourages firms to have an AC which is solely composed of independent directors. The new revisions introduced by MCCG 2012 require the board to formalize ethical standards on the setting up of the code of conduct and ensuring its compliance. Further, it requires the code of conduct to include channels that offer appropriate communication and feedback to facilitate whistle-blowing. Besides, the MCCG 2017 requests that policies and procedures on whistle-blowing should be established, reviewed and implemented by the board.

\subsection{Hypotheses Development}

Even though there are several revised CG codes (MCCG 2000, revised MCCG 2007, MCCG 2012 and currently MCCG 2017) in Malaysia, the frequency of amendments to the Code is an indication that either the Code needs to be 
improved further, or the challenges of implementing the Code may be difficult due to cultural diversity amongst Malaysian firms. The business environment in Malaysia has certain features that may affect the efficient implementation of the CG framework. Malaysian firms focus strongly on shareholdings, which have grown from the traditional family-owned business (Abdul-Rahman \& Ali, 2006; Claessens, Djankov, \& Lang, 2000). This differentiates the pattern of ownership of companies in Malaysia from other Western countries, like the UK and the US, which could compound the problems of CG (Abdullah, 2006). Conflicts of interest and information asymmetry exist in most organizations (Jensen \& Meckling, 1976). Such problems are common, especially in countries with higher family-owned firms such as Malaysia, where type II agency problem is on the increase (Ali, Chen, \& Radhakrishnan, 2007). This is because the majority shareholders tend to have greater access to information than minority shareholders (Martínez-Ferrero, Rodríguez-Ariza, \& García-Sánchez, 2016; Prommin, Jumreornvong, Jiraporn, \& Tong, 2016; Tsao, Lin, \& Chen, 2015).

Importantly, there is a big gap on the effectiveness of CG mechanisms as many of the board members have full-time jobs in other corporations and rely on the CEO, which in most cases is a family member, to provide them with relevant firm-specific information for monitoring managers' decisions (Adams \& Ferreira, 2007). However, the CEO has less inclination to disseminate information to the board, an attempt to weaken the monitoring strength of the board (Adams \& Ferreira, 2007). Consequently, Rachagan and Kuppusamy (2013) suggested an internal whistle-blowing policy for firms. Whistle-blowing policy should be made an essential part of the internal control system (Brennan \& Kelly, 2007; Meng \& Fook, 2011) to support and strengthen the link between the CG mechanisms and the internal audit function (Zain, Subramaniam, \& Stewart, 2006), thus enhancing the effectiveness of CG mechanisms (Alam, 2009; Bowen et al., 2010; Friebel \& Guriev, 2012; Mak, 2007; Meng \& Fook, 2011; Packin \& Edwards, 2016; Schultz \& Harutyunyan, 2015). Whistle-blowing, "which occurs when an employee raises concerns about a dangerous, unethical or illegal activity that he is aware of through his work" (Bursa Malaysia Corporate Governance Guide, 2013), assists the board to discover information about the agency problems (Bowen et al., 2010), which protects shareholders (Fauver \& Fuerst, 2006), as well as public interests (Alleyne, Hudaib, \& Pike, 2013).

Consequently, several regulators, such as in Japan, Indonesia, Singapore, Malaysia and Thailand, require firms to formulate a whistle-blowing policy that allows employees, primarily internal and external auditors, to directly access and freely talk to independent directors about their concerns with illegal or unethical conduct, without fear of retaliation. Shawver and Clements (2006) found that accountants are more likely to blow the whistle for acts relating to EM practices (e.g., early shipments and unfair loans). Likewise, Shawver and Shawver (2007) claimed that even if there are no protection laws for reporting accounting manipulations in private firms, there is a marginal relationship for explaining intentions of accountants to whistle-blow in situations of EM (e.g., early shipments and bad debt). A recent study conducted by Al-Absy et al. (2019a) provided evidence that CG mechanisms are more effective in mitigating the level of AEM in firms that have WBP than those without WBP. They found that BOD characteristics, (i.e., chairman independence and chairman tenure as well the AC characteristics, i.e., size, meetings and women in the committee) are significantly associated with a low level of AEM in firms that have WBP. Likewise, the ownership concentration and big four auditing firms are significantly related to the low level of AEM in firms with WBP. However, for firms without WBP, only the board chairman tenure has a significant negative relationship with AEM.

Thus, this study proposes that having an effective WBP in a firm could significantly strengthen the CG mechanisms in mitigating REM practices. This study selects the most critical mechanisms of BOD, i.e., board chairman independence, board independence, board size, board meetings and women on board, to investigate their influence on the level of REM in firms with and without WBP. It also selects the most vital mechanisms of AC, i.e., the size, meeting, independence, accounting expertise, multiple directorships and women in the committee, to investigate their influence on the level of REM in firms with and without WBP. Moreover, ownership concentration and audit firm size are also investigated. Therefore, the study proposes the following hypotheses:

$\mathrm{H}_{1}$ : Corporate governance mechanisms are more effective in mitigating real earnings management in firms that have a whistle-blowing policy than those without the policy.

\section{Research Methodology}

This study covers 300 Malaysian listed firms. The selection of these firms is based on the firms' performance using return on assets (ROA) (Burgstahler \& Dichev, 1997; Roychowdhury, 2006; Yuliana, Anshori, \& Alim, 2015). By following previous studies (Al-Absy, Ku Ismail, \& Chandren, 2017, 2018a, 2018b, 2019a, 2019b), this study used the following two steps. First, firms with negative earnings in one or more years were excluded. This is because the managers are expected to be encouraged to avoid reporting any annual losses (Burgstahler \& Dichev, 1997; Campa, 
2015; Mohd Saleh, Mohd Iskandar, \& Rahmat, 2005; Roychowdhury, 2006). Firms are more likely to maintain their positive (non-negative) earnings (Burgstahler \& Dichev, 1997; Ozili, 2019) by reducing the high earnings in good years and increasing the low earnings in bad years (Ozili \& Outa, 2017) to generate stable earnings over time (Ozili, 2019). Subsequently, 300 firms with the lowest average ROA for the years 2013, 2014 and 2015 were chosen. Firms with around zero earnings are more likely to engage in EM (Mohd Saleh et al., 2005; Roychowdhury, 2006; Yuliana et al., 2015). This argument is in line with previous studies that selected firms with ROA between zero and 0.005 in detecting EM (Roychowdhury, 2006; Yuliana et al., 2015). However, during the process, 12 firms were excluded. Therefore, the final sample for the three years is 864 firm-year observations, involving 288 firms.

This study used the three proxies of Roychowdhury (2006) adopted in previous studies (i.e., Razzaque, Ali, and Mather (2016) and Liu, Shi, Wilson, and Wu (2017)) to measure the abnormal level of REM. First, the abnormal levels of cash flow from operations (ABCFO): The study ran ordinary least squares (OLS) regression for three years and for seven sectors with specific industry and year effect to estimate the coefficients $\left(\alpha_{1}, \beta_{1}\right.$ and $\left.\beta_{2}\right)$ from the following equation:

$$
\frac{\mathrm{CFO}_{\mathrm{it}}}{\mathrm{A}_{\mathrm{it}-1}}=\alpha_{0}+\alpha_{1}\left(\frac{1}{\mathrm{~A}_{\mathrm{it}-1}}\right)+\beta_{1}\left(\frac{\mathrm{S}_{\mathrm{it}}}{\mathrm{A}_{\mathrm{it}-1}}\right)+\beta_{2}\left(\frac{\Delta \mathrm{S}_{\mathrm{it}}}{\mathrm{A}_{\mathrm{it}-1}}\right)+\varepsilon_{\mathrm{it}}
$$

Where, $\mathrm{CFO}_{\text {it }}$ is cash flow from operations, $\mathrm{A}_{\mathrm{it}-1}$ is total assets of last period, $\mathrm{S}_{\mathrm{t}}$ is the sales and $\Delta \mathrm{S}_{\mathrm{it}}$ is the change of sales. Therefore, the normal levels of operating cash flow (NCFO) were calculated by using the estimated coefficients $\alpha_{1}, \beta_{1}$ and $\beta_{2}$ from Equation 1 and applied in the following equation:

$$
N C F O=\alpha_{0}+\alpha_{1}\left(\frac{1}{A_{i t-1}}\right)+\beta_{1}\left(\frac{S_{i t}}{A_{\mathrm{it}-1}}\right)+\beta_{2}\left(\frac{\Delta S_{i t}}{A_{i t-1}}\right)+\varepsilon_{i t}
$$

Then, the ABCFO is the actual cash flow from operations minus the NCFO as per the following equation:

$$
A B C F O=\frac{\mathrm{CFO}_{\mathrm{it}}}{\mathrm{A}_{\mathrm{it}-1}}-N C F O
$$

Second, the abnormal levels of production costs (ABPROD): The study ran OLS regression for three years and for seven sectors with specific industry and year effect to estimate the coefficient value of $\alpha_{1}, \beta_{1}, \beta_{2}$ and $\beta_{3}$ from the following equation:

$$
\frac{\text { PROD }_{i t}}{A_{i t-1}}=\alpha_{0}+\alpha_{1}\left(\frac{1}{A_{i t-1}}\right)+\beta_{1}\left(\frac{S_{i t}}{A_{i t-1}}\right)+\beta_{2}\left(\frac{\Delta S_{i t}}{A_{i t-1}}\right)+\beta_{3}\left(\frac{\Delta S_{i t-1}}{A_{i t-1}}\right)+\varepsilon_{i t}
$$

PROD $_{t}$ is the sum of the cost of goods sold (COGS) and change in inventory ( $\triangle \mathrm{INV}$ ) and $\Delta \mathrm{S}_{\text {it-1 }}$ is the one year lag of $\Delta \mathrm{S}_{\mathrm{it}}$. Therefore, the normal level of production cost (NPROD) was calculated by using the estimated coefficient value of $\alpha_{1}, \beta_{1}, \beta_{2}$ and $\beta_{3}$ found from equation 4 and applied in the following equation:

$$
\text { NPROD }=\alpha_{0}+\alpha_{1}\left(\frac{1}{A_{\mathrm{it}-1}}\right)+\beta_{1}\left(\frac{\mathrm{S}_{\mathrm{it}}}{\mathrm{A}_{\mathrm{it}-1}}\right)+\beta_{2}\left(\frac{\Delta \mathrm{S}_{\mathrm{it}}}{\mathrm{A}_{\mathrm{it}-1}}\right)+\beta_{3}\left(\frac{\Delta \mathrm{S}_{\mathrm{it}-1}}{\mathrm{~A}_{\mathrm{it}-1}}\right)+\varepsilon_{\mathrm{it}}
$$

Then, the ABPROD is the actual production cost during the year minus the NPROD as the per the following equation:

$$
\mathrm{ABPROD}=\frac{\text { PROD }_{\text {it }}}{\mathrm{A}_{\mathrm{it}-1}}-\mathrm{NPROD}
$$

Third, the abnormal levels of discretionary expenses (ABDISEXP): The study ran OLS regression for three years and for seven sectors with specific industry and year effect to estimate the coefficient value of $\alpha_{1}$ and $\beta$ from the following equation:

$$
\frac{\text { DISEXP }_{\text {it }}}{A_{\text {it }-1}}=\alpha_{0}+\alpha_{1}\left(\frac{1}{A_{i t-1}}\right)+\beta\left(\frac{S_{i t-1}}{A_{i t-1}}\right)+\varepsilon_{i t}
$$

DISEXP $_{\text {it }}$ is the sum of R\&D, advertising and selling and general and administrative costs (any missing data on the 
advertising and R\&D will be replaced by zero (Nia et al., 2017)). Therefore, the normal levels of discretionary expenses (NDISEXP) were calculated by using the estimated coefficient value $\alpha_{1}$ and $\beta$ found from equation 7 and applied in the following equation:

$$
\operatorname{NDISEXP~}=\alpha_{0}+\alpha_{1}\left(\frac{1}{A_{i t-1}}\right)+\beta\left(\frac{S_{i t-1}}{A_{i t-1}}\right)+\varepsilon_{i t}
$$

Then, ABDISEXP is the actual discretionary expenses minus the NDISEPX as per the following equation:

$$
\text { ABDISEXP }=\frac{\text { DISEXP }_{i t}}{A_{i t-1}}-\text { NDISEXP }
$$

However, previous studies provided evidence that firms that engaged in increase-earnings are more likely to have low cash flows from operations, high production costs and/or low discretionary expenditures (Chen, Huang, \& Fan, 2012; Cohen, Dey, \& Lys, 2008; Cohen \& Zarowin, 2010; Ferramosca \& Ghio, 2018; Haji-Abdullah \& Wan-Hussin, 2015; Sun et al., 2014), or vice versa. Thus, to achieve consistency among variables, ABCFO and ABDISEXP were multiplied by (-1) (Chen et al., 2012; Chi, Lisic, \& Pevzner, 2011; Cohen \& Zarowin, 2010; Haji-Abdullah \& Wan-Hussin, 2015; Razzaque et al., 2016). Importantly, this study combined the value of ABCFO, ABPROD and ABDISEXP to reflect the total value of abnormal levels of REM (ABREM) as per the following equation:

$$
\mathrm{ABREM}=\mathrm{ABCFO}^{*-1}+\mathrm{ABPROD}+\mathrm{ABDISEXP}^{*-1}
$$

Following the most recent studies (Chang, Wang, Chiu, \& Huang, 2015; Francis et al., 2016; Kim \& Sohn, 2013; Kwon, Na, \& Park, 2017; Lisboa, 2016; Liu \& Wang, 2017; Xu \& Ji, 2016), this study used the absolute value of REM (ABREM) to reflect the level of REM. This study runs the regression for all firms' observation to see the influence of each mechanism of CG in mitigating REM. Further, the same regression was conducted for each group (firms with and without WBP) to investigate whether or not the mechanisms of CG in firms that have a WBP are more effective in mitigating REM than those without the policy. Several of CG mechanisms are used in the regression model. For BOD mechanisms, the regression model includes board chairman independence (BCIND); "1" if the board chairman is independent, "0" otherwise, board size (BSIZE); number of board directors, board meetings (BMEET); number of board meetings per year, board independence (BIND); proportion of board independence, and women on board (BFEM); " 1 " if the board has a female director, " 0 " otherwise.

For AC mechanisms, the regression model contains AC size (ACSIZE), number of AC meetings in a year (ACMEET), AC independence (ACIND), presence of women in the AC (ACFEM), proportion of AC with accounting expertise, (ACAE), and AC's multiple directorships (ACMD - number of AC members who are a director in other firms). Besides, two other mechanisms are also used - ownership concentration (Conc5, i.e. the proportion of shares held by the five largest shareholders) and auditor size (Big4, i.e. "1" if the firm is audited by Big4, "0" otherwise). Furthermore, several control variables are used in the regression model, i.e., sales growth (SG), leverage (LEV), return on assets (ROA), net and cash flow from operations (NCFO - " 1 " if the firm has a negative value of cash from operations, " 0 " otherwise).

The regression model used is:

REM $=\alpha+\beta_{1}$ BCIND $+\beta_{2}$ BSIZE $+\beta_{3}$ BMEET $+\beta_{4}$ BIND $+\beta_{5}$ BFEM $+\beta_{6}$ ACSIZE $+\beta_{7}$ ACMEET $+\beta_{8}$ ACIND + $\beta_{9} \mathrm{ACFEM}+\beta_{10} \mathrm{ACAE}+\beta_{11} \mathrm{ACMD}+\beta_{12} \mathrm{Conc} 5+\beta_{13} \mathrm{Big} 4+\beta_{14} \mathrm{SG}+\beta_{15} \mathrm{LEV}+\beta_{16} \mathrm{ROA}+\beta_{17} \mathrm{NCFO}+\varepsilon$.

\section{Results and Discussion}

The descriptive statistics of the CG mechanisms are presented in Table 1. The first column describes the mean value of variables for all observations together. Further, the second column shows the mean values of variables based on each group (firms with and without WBP). It also shows the significant difference between the mean value of each CG variables among firms with and without WBP. The CG mechanisms seem to be different in each group. For instance, the second column indicates that firms with WBP have significantly higher mean values for BSIZE, BMEET, BIND, BFEM, ACSIZE, ACMEET, ACFEM, ACMD, Conc5 and Big4 over those firms without WBP. This means that firms which have a policy of whistle-blowing are more likely to have: a large board and AC, higher frequency of board and AC meetings, women on boards and AC, a higher percentage of board independent directors, a higher number of directors with multiple directorships, big audit firms and higher percentage of ownership concentration. These mechanisms seem to have a positive relationship with the existence of WBP in a firm. Hence, functional and effective governance can be achieved by having a whistle-blowing policy, which is in line with agency and resource dependence theories. However, in firms without WBP, only the mean value of the existence of 
board chairman independent director is significantly higher than in firms with WBP. In terms of the firms-specific characteristics, i.e., SG, LEV, ROA and NCFO, there is no significant difference between firms with and without WBP.

Table 1. T/z-test for the variables by grouped firms into firms with and without WBP

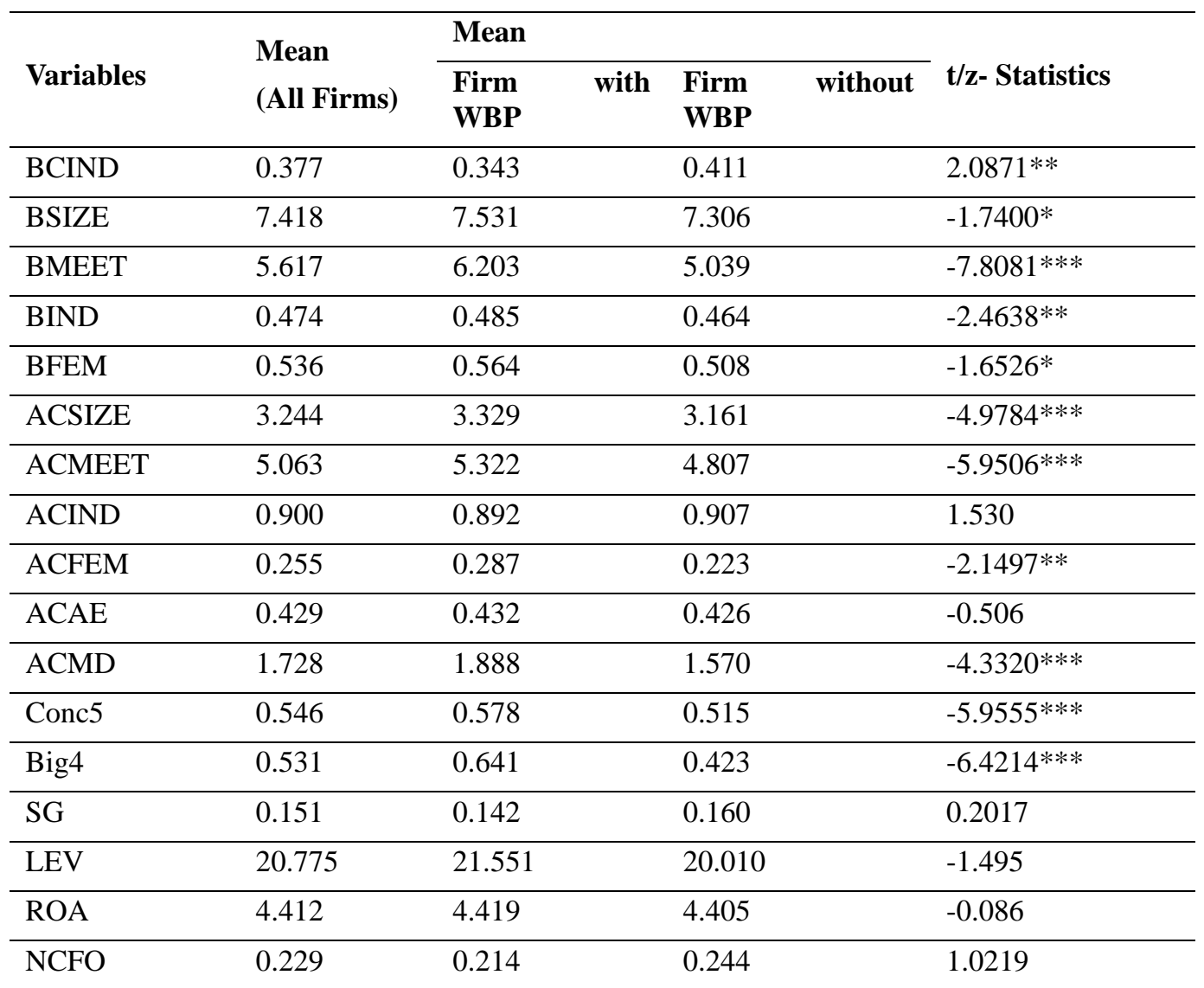

Notes: $* * * \mathrm{p}<0.01, * * \mathrm{p}<0.05,{ }^{*} \mathrm{p}<0.1$. "ttest" command in STATA employed to report the $\mathrm{t}$-value for continuous variables, while "prtest" command employed to report z-value for dummy variables (Al-Dubai, 2014). BCIND is board chairman independence, BSIZE is board size, BMEET is board meetings, BIND is board independence, BFEM is women on board, ACSIZE is AC size, ACMEET is AC meeting, ACIND is AC independence, ACFEM is women in the AC, ACAE is AC's accounting expertise, ACMD is AC's multiple directorships, Conc5 is ownership concentration, Big4 is auditor size, SG is sales growth, LEV is leverage, ROA is return on assets and NCFO is cash flow from operations.

This study conducted several diagnostic tests to find the fitness of the data, i.e., outlier, normality, multicollinearity, heteroscedasticity and autocorrelation, before running the regression analysis. For the outlier test, it is found that REM, ACMEET BMEET and SG have an outlier problem which the study winsorized the data of these variables by using the minimum level of 1\% for REM and ACMEET and 5\% for BMEET and SG. For the normality test, this study used the Kurtosis and Skewness tests; it shows that all data of the variables are normally distributed and within the threshold of \pm 3 and \pm 10 , respectively (Kline, 2015). Regarding the multicollinearity issue, the study used two methods, the variance inflation factor (VIF) and Pearson correlation, to test the correlation among variables. The results of these tests are reported in Table 2 and 3, which confirm that variables are not correlated with each other. Furthermore, the Wooldridge test suggested that there is no autocorrelation problem in the data. However, the Breusch-Pagan/Cook-Weisberg test suggests the existence of heteroscedasticity problem. 
Table 2. The variance inflation factor

\begin{tabular}{lll}
\hline Variable & VIF & $1 / \mathrm{VIF}$ \\
\hline BCIND & 1.09 & 0.919 \\
\hline BSIZE & 1.72 & 0.582 \\
\hline BMEET & 1.72 & 0.583 \\
\hline BIND & 1.92 & 0.520 \\
\hline BFEM & 1.50 & 0.669 \\
\hline ACSIZE & 1.55 & 0.644 \\
\hline ACMEET & 1.60 & 0.625 \\
\hline ACIND & 1.56 & 0.639 \\
\hline ACFEM & 1.50 & 0.665 \\
\hline ACAE & 1.05 & 0.951 \\
\hline ACMD & 1.24 & 0.810 \\
\hline Conc5 & 1.08 & 0.922 \\
\hline Big4 & 1.14 & 0.878 \\
\hline FSIZE & 1.08 & 0.926 \\
\hline LEV & 1.15 & 0.867 \\
\hline ROA & 1.09 & 0.913 \\
\hline NCFO & 1.09 & 0.918 \\
\hline Mean VIF & 1.36 & \\
\hline
\end{tabular}

Table 3. Pearson correlation test

\begin{tabular}{|c|c|c|c|c|c|c|c|c|c|}
\hline & 1 & 2 & 3 & 4 & 5 & 6 & 7 & 8 & 9 \\
\hline 1. REM & 1 & & & & & & & & \\
\hline 2.BCHIND & 0.03 & 1 & & & & & & & \\
\hline 3. BSIZE & $-0.09 * *$ & -0.05 & 1 & & & & & & \\
\hline 4.BMEET & -0.04 & $-0.06^{*}$ & $0.20 * * *$ & 1 & & & & & \\
\hline 5.BIND & 0.05 & $0.18 * * *$ & $-0.32 * * *$ & $0.07 *$ & 1 & & & & \\
\hline 6.BFEM & 0.00 & $-0.12 * * *$ & $0.15 * * *$ & $0.06^{*}$ & $-0.10 * * *$ & 1 & & & \\
\hline 7.ACSIZE & $-0.09 * * *$ & 0.03 & $0.31 * * *$ & $0.27 * * *$ & $0.20 * * *$ & 0.01 & 1 & & \\
\hline 8.ACMEET & $-0.06 *$ & $-0.14 * * *$ & $0.14 * * *$ & $0.59 * * *$ & 0.04 & $0.08 * *$ & $0.14 * * *$ & 1 & \\
\hline 9.ACIND & 0.01 & $0.07 *$ & $0.10 * * *$ & $-0.08 * *$ & $0.41 * * *$ & $-0.06 *$ & $-0.08 * *$ & 0.00 & 1 \\
\hline 10.ACFEM & 0.02 & $-0.07 *$ & $0.08 * *$ & $0.11 * * *$ & -0.05 & $0.54 * * *$ & $0.08 * *$ & $0.09 * *$ & $-0.14 * * *$ \\
\hline 11.ACAE & 0.05 & 0.00 & -0.03 & -0.02 & -0.04 & $0.08 * *$ & $-0.15 * * *$ & 0.02 & $0.07 * *$ \\
\hline 12.ACMD & -0.06 & 0.03 & $0.23 * * *$ & $0.18 * * *$ & $0.11 * * *$ & 0.00 & $0.37 * * *$ & $0.16 * * *$ & 0.01 \\
\hline 13.Conc5 & $0.07 * *$ & $-0.11 * * *$ & 0.05 & $0.14 * * *$ & $-0.09 * * *$ & 0.05 & $0.09 * *$ & $0.07 * *$ & $-0.13 * * *$ \\
\hline 14.Big4 & -0.05 & -0.05 & $0.12 * * *$ & $0.16 * * *$ & 0.04 & $0.09 * * *$ & $0.20 * * *$ & $0.11 * * *$ & $-0.08 * *$ \\
\hline 15.SG & $0.07 * *$ & 0.03 & 0.03 & -0.02 & $-0.06^{*}$ & 0.03 & $-0.06 *$ & 0.01 & 0.02 \\
\hline 16.LEV & -0.05 & -0.02 & $0.14 * * *$ & $0.08 * *$ & $-0.11 * * *$ & $-0.11 * * *$ & -0.01 & $0.13 * * *$ & 0.03 \\
\hline 17.ROA & 0.06 & -0.03 & $0.08 * *$ & 0.00 & $-0.06 *$ & 0.05 & 0.00 & -0.05 & $-0.06^{*}$ \\
\hline 18.NCFO & $0.16 * * *$ & $0.08 * *$ & -0.05 & 0.04 & 0.02 & $-0.06 *$ & -0.03 & -0.01 & $0.12 * * *$ \\
\hline
\end{tabular}


Continued

\begin{tabular}{|c|c|c|c|c|c|c|c|c|c|}
\hline & 10 & 11 & 12 & 13 & 14 & 15 & 16 & 17 & 18 \\
\hline 10.ACFEM & 1 & & & & & & & & \\
\hline 11.ACAE & 0.02 & 1 & & & & & & & \\
\hline 12.ACMD & 0.01 & 0.02 & 1 & & & & & & \\
\hline 13.Conc5 & $0.11 * * *$ & -0.01 & $0.09 * * *$ & 1 & & & & & \\
\hline 14.Big4 & $0.14 * * *$ & 0.03 & $0.15^{* * *}$ & $0.09 * * *$ & 1 & & & & \\
\hline 15.SG & 0.02 & -0.03 & -0.06 & 0.03 & -0.05 & 1 & & & \\
\hline 16.LEV & $-0.13 * * *$ & 0.00 & $0.09 * * *$ & $-0.08 * *$ & $0.13 * * *$ & 0.05 & 1 & & \\
\hline 17.ROA & -0.01 & 0.01 & -0.01 & 0.00 & 0.02 & $0.21 * * *$ & $-0.10 * * *$ & 1 & \\
\hline 18.NCFO & -0.03 & 0.03 & -0.04 & $-0.08 * *$ & $-0.12 * * *$ & $0.06 * *$ & $0.12 * * *$ & $-0.08 * *$ & 1 \\
\hline
\end{tabular}

Notes: *** $\mathrm{p}<0.01, * * \mathrm{p}<0.05, * \mathrm{p}<0.1$. REM is sum value of the three proxies introduced by Roychowdhury (2006), BCIND is board chairman independence, BSIZE is board size, BMEET is board meetings, BIND is board independence, BFEM is women on board, ACSIZE is AC size, ACMEET is AC meeting, ACIND is AC independence, ACFEM is women in the AC, ACAE is AC's accounting expertise, ACMD is AC's multiple directorships, Conc5 is ownership concentration, Big4 is auditor size, SG is sales growth, LEV is leverage, ROA is return on assets and NCFO is cash flow from operations.

Based on the above assumption tests, it is suggested that feasible generalized least squares (FGLS) regression provides reliable estimates in the presence of heteroscedasticity (Wooldridge, 2010). Thus, FGLS regression was used with option "panels (heteroskedastic)" to solve the problem of heteroscedasticity (Podestà, 2002; StataCorp, 2015) which has been adopted by previous studies (Buckley, Elia, \& Kafouros, 2014; Cai, Luo, \& Wan, 2012; Luo, Wan, Cai, \& Liu, 2013; Sakawa \& Watanabel, 2017, 2018; Yoshikawa \& Rasheed, 2010). The results of FGLS regression are shown in Table 4. For all firms' observations, ACSIZE, ACMEET and Big4 are significantly associated with a low level of REM. These results are consistent with agency and resource dependence theories. Conversely, other mechanisms of CG, i.e., BIND, ACAE and Conc5 are found to be significantly associated with a high level of REM, while the rest of CG mechanisms are found to be not associated with the level REM. These results are inconsistent with the agency and resource dependence theories.

Table 4 also shows the results of the re-estimate model by grouping all firms' observations into firms with and without WBP. In firms without WBP, only BMEET, ACMD and Big4 are found to be significantly associated with a low level of REM, which is consistent with agency and resource dependence theories. However, most of the CG mechanisms are found to be not effective in mitigating the level of REM. It seems that CG mechanisms have been dominated by the management where some of these mechanisms resulted in a significantly high level of REM. For instance, CG mechanisms, i.e., ACSIZE, ACFEM, ACAE and Conc5, are found to be significantly associated with a high level of REM. These results indicate that CG mechanisms in firms without WBP do not adequately monitor the managers' discretion where the directors may face difficulties in accessing firms' information regarding the financial reporting process or attempt to work alongside with management to mask the figure of earnings in order to retain their position. Regarding firms with WBP, most of the CG mechanisms, i.e., ACSIZE, ACMEET, ACIND and Big4, are found to be significantly associated with a low level of REM, supporting agency and resource dependence theories. However, only BIND and Conc5 are found to be significantly associated with a high level of REM. From these results, it appears that having WBP in a firm slightly improved the monitoring role of the CG mechanisms towards mitigating REM. These results indicate that WBP needs to be further strengthen to enhance the monitoring role of CG in mitigating REM. Indeed, daily operational activities are more complex. Therefore, there is a need for more policies and efforts to encourage whistle-blowers to disclose any misconducts to directors.

Regarding the control variables, this study finds the same result for the influence of ROA and NCFO on REM. Table 4 shows that ROA and NCFO are significantly associated with a high level of REM for all firms' observations and each group, either firms with and without WBP. In terms of sales growth (SG), this study reveals that SG is significantly associated with a high level of REM in all firms' observation and firms with WBP while not for firms without WBP. Further, this study finds that LEV is significantly associated with a low level of REM in only firms without WBP. 
Table 4. FGLS regression of the main models

\begin{tabular}{|c|c|c|c|c|c|c|}
\hline \multirow{2}{*}{ DA } & \multicolumn{2}{|l|}{ All firms } & \multicolumn{2}{|c|}{ Firms without WBP } & \multicolumn{2}{|c|}{ Firms with WBP } \\
\hline & Coef. & $\mathbf{Z}$ & Coef. & $\mathbf{z}$ & Coef. & $\mathbf{z}$ \\
\hline BCIND & -0.002 & -0.45 & -0.000 & -0.02 & -0.003 & -0.48 \\
\hline BSIZE & -0.001 & -0.99 & -0.000 & -0.25 & -0.001 & -0.25 \\
\hline BMEET & -0.001 & -0.45 & $-0.007 * * *$ & -2.76 & 0.002 & 0.96 \\
\hline BIND & $0.062 * *$ & 2.53 & -0.002 & -0.07 & $0.163 * * *$ & 4.91 \\
\hline BFEM & 0.002 & 0.42 & -0.007 & -1.07 & 0.008 & 1.11 \\
\hline ACSIZE & $-0.011 * *$ & -2.23 & $0.012^{*}$ & 1.83 & $-0.036 * * *$ & -4.88 \\
\hline ACMEET & $-0.006 * *$ & -2.59 & -0.004 & -1.24 & $-0.009 * * *$ & -3.65 \\
\hline ACIND & -0.022 & -1.19 & 0.008 & 0.31 & $-0.074 * *$ & -2.51 \\
\hline ACFEM & 0.008 & 1.43 & $0.017 * *$ & 2.20 & 0.012 & 1.45 \\
\hline ACAE & $0.020^{*}$ & 1.80 & $0.031 * *$ & 1.96 & -0.004 & -0.21 \\
\hline $\mathrm{ACMD}$ & -0.003 & -1.31 & $-0.007 * * *$ & -2.77 & 0.001 & 0.23 \\
\hline Conc5 & $0.058 * * *$ & 3.89 & $0.039 * *$ & 1.98 & $0.065 * * *$ & 2.94 \\
\hline Big4 & $-0.013 * * *$ & -3.14 & $-0.010^{*}$ & -1.92 & $-0.026 * * *$ & -3.98 \\
\hline $\mathrm{SG}$ & $0.026 * * *$ & 3.25 & 0.001 & 0.10 & $0.061 * * *$ & 4.70 \\
\hline LEV & 0.000 & -0.65 & $-0.000 *$ & -1.82 & 0.000 & 0.84 \\
\hline ROA & $0.003 * * *$ & 3.41 & $0.003 * *$ & 2.46 & $0.002 *$ & 1.72 \\
\hline $\mathrm{NCFO}$ & $0.052 * * *$ & 9.33 & $0.045 * * *$ & 5.85 & $0.049 * * *$ & 7.12 \\
\hline _cons & $0.126 * * *$ & 5.33 & $0.086 * * *$ & 2.61 & $0.211^{* * * *}$ & 5.78 \\
\hline Wald chi ${ }^{2}$ & & 225.06 & & 92.54 & & 542.80 \\
\hline Prob > chi ${ }^{2}$ & & 0.0000 & & 0.0000 & & 0.0000 \\
\hline $\mathrm{R}^{2}$ & & 0.0640 & & 0.0587 & & 0.1016 \\
\hline Obs. & & 864 & & 435 & & 429 \\
\hline
\end{tabular}

Notes: $* * * \mathrm{p}<0.01, * * \mathrm{p}<0.05, * \mathrm{p}<0.1 . \mathrm{R}^{2}$ calculated by OLS regression. REM is sum value of the three proxies introduced by Roychowdhury (2006), BCIND is board chairman independence, BSIZE is board size, BMEET is board meetings, BIND is board independence, BFEM is women on board, ACSIZE is AC size, ACMEET is AC meeting, ACIND is AC independence, ACFEM is women in the AC, ACAE is AC's accounting expertise, ACMD is AC's multiple directorships, Conc5 is ownership concentration, Big4 is auditor size, SG is sales growth, LEV is leverage, ROA is return on assets and NCFO is cash flow from operations.

\subsection{Robustness Test}

There is no definitive agreement on the calculation method of REM. In contrast to the method that was used in this study, some previous studies have used the standardized value of ABCFO, ABPROD and ABDISEXP (Chen et al., 2012; Chen, Cheng, \& Wang, 2011; Chi et al., 2011; Cohen et al., 2008; Cohen \& Zarowin, 2010; Haji-Abdullah \& Wan-Hussin, 2015; Liu \& Tsai, 2015) to calculate the aggregate value of REM. Therefore, this study re-estimates the model by using the absolute value of the sum of the standardized ABCFO, ABPROD and ABDISEXP to examine the robustness of the findings found from the main model. The results in Table 5 show the same results as in Table 4 , except for ACFEM and ACAE in the total firms model as well as ACSIZE and Big4 in the firm without WBP. This means that there is no significant difference in the results, either using the standardized or non-standardized values. 
Table 5. FGLS regression by standardizing the value of REM proxies

\begin{tabular}{|c|c|c|c|c|c|c|}
\hline \multirow{2}{*}{ DA } & \multicolumn{2}{|l|}{ All firms } & \multicolumn{2}{|c|}{ Firms without WBP } & \multicolumn{2}{|c|}{ Firms with WBP } \\
\hline & Coef. & $\mathbf{z}$ & Coef. & $\mathbf{Z}$ & Coef. & $\mathbf{Z}$ \\
\hline BCIND & -0.012 & -0.26 & -0.006 & -0.10 & 0.010 & 0.14 \\
\hline BSIZE & -0.012 & -0.75 & 0.005 & 0.22 & 0.023 & 0.97 \\
\hline BMEET & -0.002 & -0.09 & $-0.093 * * *$ & -3.62 & 0.022 & 1.02 \\
\hline BIND & $0.611 * *$ & 2.27 & 0.232 & 0.64 & $1.844 * * *$ & 5.11 \\
\hline BFEM & -0.042 & -0.81 & -0.109 & -1.57 & 0.089 & 1.17 \\
\hline ACSIZE & $-0.209 * * *$ & -3.94 & 0.074 & 1.10 & $-0.476 * * *$ & -6.31 \\
\hline ACMEET & $-0.083 * * *$ & -3.58 & -0.038 & -1.02 & $-0.115^{* * *}$ & -4.86 \\
\hline ACIND & -0.280 & -1.38 & -0.205 & -0.76 & $-1.068 * * *$ & -3.23 \\
\hline ACFEM & $0.143 * *$ & 2.37 & $0.158 *$ & 1.91 & 0.064 & 0.65 \\
\hline $\mathrm{ACAE}$ & 0.196 & 1.51 & $0.442 * * *$ & 2.66 & -0.053 & -0.24 \\
\hline ACMD & 0.008 & 0.37 & $-0.049 *$ & -1.65 & 0.032 & 0.76 \\
\hline Conc5 & $0.694 * * *$ & 4.35 & $0.497 * *$ & 2.44 & $0.851 * * *$ & 3.50 \\
\hline Big4 & $-0.101 * *$ & -2.23 & -0.035 & -0.61 & $-0.304 * * *$ & -4.05 \\
\hline SG & $0.324 * * *$ & 3.25 & -0.083 & -0.62 & $0.857 * * *$ & 5.59 \\
\hline LEV & -0.001 & -0.41 & $-0.003 *$ & -1.67 & 0.002 & 0.80 \\
\hline $\mathrm{ROA}$ & $0.035 * * *$ & 3.94 & $0.041 * * *$ & 3.34 & $0.051 * * *$ & 3.44 \\
\hline $\mathrm{NCFO}$ & $0.685 * * *$ & 12.69 & $0.641 * * *$ & 7.97 & $0.642 * * *$ & 10.63 \\
\hline _cons & $1.688 * * *$ & 6.69 & $1.084 * * *$ & 3.17 & $2.432 * * *$ & 5.80 \\
\hline Wald chi ${ }^{2}$ & & 331.97 & & 134.22 & & 2133.99 \\
\hline Prob>chi ${ }^{2}$ & & 0.0000 & & 0.0000 & & 0.0000 \\
\hline $\mathrm{R}^{2}$ & & 0.0624 & & 0.0695 & & 0.0942 \\
\hline Obs. & & 864 & & 435 & & 429 \\
\hline
\end{tabular}

Notes: $* * * \mathrm{p}<0.01, * * \mathrm{p}<0.05, * \mathrm{p}<0.1 . \mathrm{R}^{2}$ calculated by OLS regression. REM is sum of the standardized value of the three proxies introduced by Roychowdhury (2006), BCIND is board chairman independence, BSIZE is board size, BMEET is board meetings, BIND is board independence, BFEM is women on board, ACSIZE is AC size, ACMEET is AC meeting, ACIND is AC independence, ACFEM is women in the AC, ACAE is AC's accounting expertise, ACMD is AC's multiple directorships, Conc5 is ownership concentration, Big4 is auditor size, SG is sales growth, LEV is leverage, ROA is return on assets and NCFO is cash flow from operations.

Furthermore, previous studies have included the year dummy variable in the regression (Buckley et al., 2014; Cai et al., 2012; Luo et al., 2013; Sakawa \& Watanabel, 2017, 2018) in order to observe the general trend over time. It is argued that years (business cycle) may have a specific effect on the result of the regression (see Baatwah, Salleh, \& Ahmad, 2015; Datta, Iskandar-Datta, \& Singh, 2013). The inclusion of year dummy variable may be necessary, particularly in the field of EM, where manipulated earnings would enable managers to transfer earnings between periods in which downward earnings in the current year are adjusted upward in the succeeding year, or vice versa (Abdullah \& Ku Ismail, 2016; Ferramosca \& Ghio, 2018; Healy, 1985). Thus, this study re-estimates the model by including the year dummy variable to test the robustness of the results reported in Table 4. Table 6 shows the results of the re-run models, which are all consistent with the previous results presented in Table 4, except for ACSIZE and Big4 in the regression of firm without WBP. 
Table 6. FGLS regression by including the year dummy variable

\begin{tabular}{|c|c|c|c|c|c|c|}
\hline \multirow{2}{*}{ DA } & \multicolumn{2}{|l|}{ All firms } & \multicolumn{2}{|c|}{ Firms without WBP } & \multicolumn{2}{|c|}{ Firms with WBP } \\
\hline & Coef. & $\mathbf{Z}$ & Coef. & $\mathbf{Z}$ & Coef. & $\mathbf{Z}$ \\
\hline BCIND & -0.003 & -0.55 & 0.000 & 0.05 & -0.003 & -0.53 \\
\hline BSIZE & -0.002 & -1.10 & -0.001 & -0.50 & -0.001 & -0.28 \\
\hline BMEET & -0.001 & -0.39 & $-0.007 * * *$ & -2.96 & 0.003 & 1.52 \\
\hline BIND & $0.063 * *$ & 2.55 & -0.008 & -0.25 & $0.154 * * *$ & 4.47 \\
\hline BFEM & 0.002 & 0.42 & -0.007 & -1.04 & 0.007 & 0.98 \\
\hline ACSIZE & $-0.011 * *$ & -2.16 & 0.011 & 1.57 & $-0.037 * * *$ & -4.97 \\
\hline ACMEET & $-0.006 * * *$ & -2.68 & -0.003 & -0.76 & $-0.009 * * *$ & -3.67 \\
\hline ACIND & -0.022 & -1.16 & 0.001 & 0.04 & $-0.066 * *$ & -2.24 \\
\hline ACFEM & 0.008 & 1.36 & $0.020 * * *$ & 2.76 & 0.010 & 1.18 \\
\hline $\mathrm{ACAE}$ & $0.019 *$ & 1.63 & $0.031 * *$ & 2.16 & -0.004 & -0.21 \\
\hline ACMD & -0.003 & -1.23 & $-0.008 * * *$ & -2.80 & 0.001 & 0.32 \\
\hline Conc5 & $0.058 * * *$ & 3.90 & $0.037 *$ & 1.85 & $0.066^{* * *} *$ & 2.97 \\
\hline Big4 & $-0.013 * * *$ & -3.10 & -0.008 & -1.55 & $-0.027 * * *$ & -4.10 \\
\hline SG & $0.026 * * *$ & 3.05 & -0.001 & -0.06 & $0.060 * * *$ & 4.33 \\
\hline LEV & 0.000 & -0.70 & $0.000^{*}$ & -1.85 & 0.000 & 0.80 \\
\hline ROA & $0.003 * * *$ & 3.35 & $0.003 * *$ & 2.53 & $0.002 *$ & 1.87 \\
\hline $\mathrm{NCFO}$ & $0.052 * * *$ & 9.36 & $0.045^{* * *}$ & 5.82 & $0.051 * * *$ & 7.11 \\
\hline _cons & $0.128 * * *$ & 5.34 & $0.111 * * *$ & 3.44 & $0.200 * * *$ & 5.31 \\
\hline Year dummy & & Included & & Included & & Included \\
\hline Wald chi2 & & 218.92 & & 130.55 & & 381.24 \\
\hline Prob > chi 2 & & 0.0000 & & 0.0000 & & 0.0000 \\
\hline $\mathrm{R}^{2}$ & & 0.0650 & & 0.0627 & & 0.1024 \\
\hline Obs. & & 864 & & 435 & & 429 \\
\hline
\end{tabular}

Notes: $* * * \mathrm{p}<0.01, * * \mathrm{p}<0.05, * \mathrm{p}<0.1 . \mathrm{R}^{2}$ calculated by OLS regression. Year dummy variables (year 2013,2014 and 2015) included as control variables. REM is sum value of the three proxies introduced by Roychowdhury (2006), BCIND is board chairman independence, BSIZE is board size, BMEET is board meetings, BIND is board independence, BFEM is women on board, ACSIZE is AC size, ACMEET is AC meeting, ACIND is AC independence, ACFEM is women in the AC, ACAE is AC's accounting expertise, ACMD is AC's multiple directorships, Conc5 is ownership concentration, Big4 is auditor size, SG is sales growth, LEV is leverage, ROA is return on assets and NCFO is cash flow from operations.

\section{Conclusion}

The study on whistle-blowing is quite new in Malaysia (Ahmad et al., 2013). Since strategies for implementing EM is a well-kept secret among corporate executives (Elias, 2002), a study on whistle-blowing is very much needed to guide practitioners and Malaysian authorities on policies and practices that can encourage staff to expose organizational wrongdoings (Ahmad et al., 2013). A policy like whistle-blowing is necessary to motivate the internal and external auditors, employees and other parties, to freely raise their concerns on EM practices to directors, who in most cases do not have enough time, energy and authority to fulfil their work. This could support and strengthen the effectiveness of CG mechanisms in mitigating EM practices. Hence, this study attempts to investigate whether CG mechanisms in firms that have a WBP are more effective in constraining REM than those without WBP. The results show that most of the CG mechanisms, i.e., ACSIZE, ACMEET, ACIND and Big4 in firms with WBP are found to 
be significantly associated with a low level of REM, supporting agency and resource dependence theories. However, only BIND and Conc5 are found to be significantly associated with a high level of REM. Regarding firms without WBP, most of the CG mechanisms, i.e., ACSIZE, ACFEM, ACAE and Conc5, are found to be significantly associated with a high level of REM. However, only BMEET, ACMD and Big4 are found to be significantly associated with a low level of REM. The finding of this study suggests that having WBP in a firm could improve the monitoring role of the CG mechanisms towards mitigating REM. Therefore, this study recommends to shareholders and policymakers to have an improved effect of WBP in a firm. Moreover, policymakers need to legislate provisions that can regulate WBP and at the same time protect honest whistle-blowers from adverse reactions from other parties. Moreover, this study recommends future studies to explore the determinants of the whistle-blowing policy that may enhance its role in improving the monitoring role of CG mechanisms and therefore, enhancing the financial reporting quality.

\section{Acknowledgement}

We wish to thank Universiti Utara Malaysia for funding this research.

\section{References}

Abdullah, S. N. (2006). Board structure and ownership in Malaysia: The case of distressed listed companies. Corporate Governance: The International Journal of Business in Society, 6(5), 582-594.

Abdullah, S. N., \& Ku Ismail, K. N. I. (2012). Do women directors constraint accrual management? Malaysian evidence. Paper presented at the 3rd International Conference on Business and Economics Victoria \& Alfrred Waterfront Hotel, Cape Town, South Africa.

Abdullah, S. N., \& Ku Ismail, K. N. I. (2016). Women directors, family ownership and earnings management in Malaysia. Asian Review of Accounting, 24(4), 525-550. https://doi.org/10.1108/ARA-07-2015-0067

Abdul-Rahman, R., \& Ali, F. H. M. (2006). Board, audit committee, culture and earnings management: Malaysian evidence. Managerial Auditing Journal, 21(7), 783-804. https://doi.org/10.1108/02686900610680549

Adams, R. B., \& Ferreira, D. (2007). A theory of friendly boards. The Journal of Finance, 62(1), 217-250.

Ahmad, S. A., Ismail, I. S., \& Azmi, N. A. (2013). Exploring internal auditors' whistleblowing intentions towards corporate fraud: A prosocial behaviour perspective. Paper presented at the Recent Trends in Social and Behaviour Sciences: Proceedings of the International Congress on Interdisciplinary Behaviour and Social Sciences (pp. 463-467). London, UK. https://doi.org/10.1201/b16658-83

Ahmed, S. (2017). Board of director characteristics and earnings management in Malaysia. GSTF Journal on Business Review (GBR), 2(4), 94-99.

Al-Absy, M. S. M., \& Ku Ismail, K. N. I. (2019). Accountants' perception on the factors affecting the adoption of international financial reporting standards in Yemen. International Journal of Financial Research, 10(4), 128-142. https://doi.org/10.5430/ijfr.v10n4p128

Al-Absy, M. S. M., Ku Ismail, K. N. I., \& Al-Dubai, S. A. (2016). Accountants' perceptions on the adoption of international financial reporting standards in Yemen. International Journal of Economics and Financial Issues, 6(4), 1911-1917.

Al-Absy, M. S. M., Ku Ismail, K. N. I., \& Chandren, S. (2017). Board chairmen's involvement in audit committees and earnings management. https://doi.org/10.2139/ssrn.3063845

Al-Absy, M. S. M., Ku Ismail, K. N. I., \& Chandren, S. (2018a). Accounting expertise in the audit committee and earnings management. Business and Economic Horizons, 14(3), 451-476. https://doi.org/10.15208/beh.2018.33

Al-Absy, M. S. M., Ku Ismail, K. N. I., \& Chandren, S. (2018b). Board chairmen's involvement in the nomination and remuneration committees and earnings management. Australasian Accounting, Business and Finance Journal, 12(4), 60-76. https://doi.org/10.14453/aabfj.v12i4.5

Al-Absy, M. S. M., Ku Ismail, K. N. I., \& Chandren, S. (2019a). Corporate governance mechanisms, whistle-blowing policy and earnings management practices of firms in Malaysia. International Journal of Business, Human and Social Sciences, 13(6), 917-922. https://doi.org/10.5281/zenodo.3299765

Al-Absy, M. S. M., Ku Ismail, K. N. I., \& Chandren, S. (2019b). Corporate governance mechanisms and family directives: aggressive or conservative in earnings' management?. Academy of Accounting and Financial Studies Journal, 23(1), 1-9. 
Alam, H. B. S. M. N. (2009). Whistleblowing and corporate governance: Accidental allies or lifetime partners? Paper presented at the International Conference on Corporate Law (ICCL), Surabaya, Indonesia.

Al-Dubai, S. A. A. W. (2014). Family involvement and firm performance: Evidence from Saudi Arabia. Doctoral dissertation, Universiti Utara Malaysia, Kedah, Malaysia.

Ali, A., Chen, T.-Y., \& Radhakrishnan, S. (2007). Corporate disclosures by family firms. Journal of Accounting and Economics, 44(1), 238-286. https://doi.org/10.1016/j.jacceco.2007.01.006

Alleyne, P., Hudaib, M., \& Pike, R. (2013). Towards a conceptual model of whistle-blowing intentions among external auditors. The British Accounting Review, 45(1), 10-23. https://doi.org/10.1016/j.bar.2012.12.003

Al-Rassas, A. H., \& Kamardin, H. (2015). Internal and external audit attributes, audit committee characteristics, ownership concentration and earnings quality: Evidence from Malaysia. Mediterranean Journal of Social Sciences, 6(3), 458-470. https://doi.org/10.5901/mjss.2015.v6n3p458

Al-Rassas, A. H., \& Kamardin, H. (2016). Earnings quality and audit attributes in high concentrated ownership market. Corporate Governance: The International Journal of Business in Society, 16(2), 377-399.

Alves, S. (2012). Ownership structure and earnings management: Evidence from Portugal. Australasian Accounting, Business and Finance Journal, 6(1), 57-74.

Al-Zyoud, A. A.-N. (2012). The effects of chairman independence and ownership structure on earnings management. World Applied Sciences Journal, 17(8), 934-940.

Ayedh, A. M., Fatima, A., \& Mohammad, M. H. S. (2019). Earnings management in Malaysian companies during the global financial crisis and the coincidental effect of IFRS Adoption. Australasian Accounting, Business and Finance Journal, 13(1), 4-26. https://doi.org/10.14453/aabfj.v13i1.2

Baatwah, S. R., Salleh, Z., \& Ahmad, N. (2015). CEO characteristics and audit report timeliness: do CEO tenure and financial expertise matter?. Managerial Auditing Journal, 30(8/9), 998-1022.

Baccouche, S., \& Omri, A. (2014). Multiple directorships of board members and earnings management: An empirical evidence from French listed companies. Journal of Economic and Financial Modelling, 2(1), 13-23.

Baccouche, S., Hadriche, M., \& Omri, A. (2013). The impact of audit committee multiple-directorships on earnings management: Evidence from France. Journal of Applied Business Research, 29(5), 1333-1342.

Bowen, R. M., Call, A. C., \& Rajgopal, S. (2010). Whistle-blowing: Target firm characteristics and economic consequences. The Accounting Review, 85(4), 1239-1271. https://doi.org/10.2308/accr.2010.85.4.1239

Boyd, B. (1990). Corporate linkages and organizational environment: A test of the resource dependence model. Strategic Management Journal, 11(6), 419-430. https://doi.org/10.1002/smj.4250110602

Brennan, N., \& Kelly, J. (2007). A study of whistleblowing among trainee auditors. The British Accounting Review, 39(1), 61-87. https://doi.org/10.1016/j.bar.2006.12.002

Buckley, P. J., Elia, S., \& Kafouros, M. (2014). Acquisitions by emerging market multinationals: Implications for firm performance. Journal of World Business, 49(4), 611-632. https://doi.org/10.1016/j.jwb.2013.12.013

Buniamin, S., Johari, N. H., Rahman, N. R. A., \& Rauf, F. H. A. (2012). Board diversity and discretionary accruals of the Top 100 Malaysia corporate governance (MCG) index company. African Journal of Business Management, 6(29), 8496-8503. https://doi.org/10.5897/AJBM11.1052

Burgstahler, D., \& Dichev, I. (1997). Earnings management to avoid earnings decreases and losses. Journal of Accounting and Economics, 24(1), 99-126. https://doi.org/10.1016/S0165-4101(97)00017-7

Bursa Malaysia Corporate Governance Guide. (2013). Corporate governance guide: towards boardroom excellence. Kuala Lumpur, Malaysia: Bursa Malaysia.

Cai, D., Luo, J.-H., \& Wan, D.-F. (2012). Family CEOs: Do they benefit firm performance in China?. Asia Pacific Journal of Management, 29(4), 923-947. https://doi.org/10.1007/s10490-012-9318-4

Campa, D. (2015). The impact of SME's pre-bankruptcy financial distress on earnings management tools. International Review of Financial Analysis, 42, 222-234. https://doi.org/10.1016/j.irfa.2015.07.004

Chandrasegaram, R., Rahimansa, M. R., Rahman, S. K., Abdullah, S., \& Mat, N. N. (2013). Impact of audit committee characteristics on earnings management in Malaysian public listed companies. International Journal of Finance and Accounting, 2(2), 114-119. 
Chandren, S. (2016). Review on the double side of earnings management. Pertanika Journal of Social Sciences \& Humanities, 24(4), 1253 - 1265.

Chandren, S., Ahmad, Z., \& Ali, R. (2015). Corporate governance mechanisms and accretive share buyback to meet or beat earnings per share forecast. International Journal of Business and Society, 16(3), 344-363.

Chandren, S., Ahmad, Z., \& Ali, R. (2017). The impact of accretive share buyback on long-term firm performance. International Journal of Economics and Management, 11(1), 49-66.

Chang, S.-H., Wang, T.-S., Chiu, A. A., \& Huang, S. Y. (2015). Earnings management and idiosyncratic risk-evidence from the post-Sarbanes-Oxley Act period. Investment Management and Financial Innovations, 12(2), 117-126.

Chen, C.-L., Huang, S.-H., \& Fan, H.-S. (2012). Complementary association between real activities and accruals-based manipulation in earnings reporting. Journal of Economic Policy Reform, 15(2), 93-108.

Chen, X., Cheng, Q., \& Wang, X. (2011). Does increased board independence reduce earnings management: Evidence from recent regulatory reforms. Working Paper, University of Wisconsin-Madison, Chinese University of Hong Kong.

Cheung, S. Y., \& Chan, B. Y. (2004). Corporate governance in Asia. Asia Pacific Development Journal, 11(2), 1-32.

Chi, W., Lisic, L. L., \& Pevzner, M. (2011). Is enhanced audit quality associated with greater real earnings management?. Accounting Horizons, 25(2), 315-335. https://doi.org/10.2308/acch-10025

Claessens, S., \& Fan, J. P. (2002). Corporate governance in Asia: A survey. International Review of Finance, 3(2), 71-103. https://doi.org/10.1111/1468-2443.00034

Claessens, S., Djankov, S., \& Lang, L. H. (2000). The separation of ownership and control in East Asian corporations. Journal of Financial Economics, 58(1), 81-112. https://doi.org/10.1016/S0304-405X(00)00067-2

Cohen, D. A., \& Zarowin, P. (2010). Accrual-based and real earnings management activities around seasoned equity offerings. Journal of Accounting and Economics, 50(1), 2-19. https://doi.org/10.1016/j.jacceco.2010.01.002

Cohen, D. A., Dey, A., \& Lys, T. Z. (2008). Real and accrual-based earnings management in the pre-and post-Sarbanes-Oxley periods. The Accounting Review, 83(3), 757-787.

Datta, S., Iskandar-Datta, M., \& Singh, V. (2013). Product market power, industry structure, and corporate earnings management. Journal of Banking \& Finance, 37(8), 3273-3285. https://doi.org/10.1016/j.jbankfin.2013.03.012

Enomoto, M., Kimura, F., \& Yamaguchi, T. (2015). Accrual-based and real earnings management: An international comparison for investor protection. Journal of Contemporary Accounting \& Economics, 11(3), 183-198.

Fama, E. F., \& Jensen, M. C. (1983). Separation of ownership and control. The Journal of Law \& Economics, 26(2), 301-325. https://doi.org/10.1086/467037

Fauver, L., \& Fuerst, M. E. (2006). Does good corporate governance include employee representation? Evidence from German corporate boards. Journal of Financial Economics, 82(3), 673-710.

Ferramosca, S., \& Ghio, A. (2018). Earnings management in family firms. Accounting Choices in Family Firms (pp. 103-138). Cham: Springer. https://doi.org/10.1007/978-3-319-73588-7_3

Francis, B., Hasan, I., \& Li, L. (2016). A cross-country study of legal-system strength and real earnings management. Journal of Accounting and Public Policy, 35(5), 477-512. https://doi.org/10.1016/j.jaccpubpol.2016.06.004

Friebel, G., \& Guriev, S. (2012). Whistle-blowing and incentives in firms. Journal of Economics \& Management Strategy, 21(4), 1007-1027. https://doi.org/10.1111/j.1530-9134.2012.00354.x

Habbash, M. (2011). The role of corporate governance regulations in constraining earnings management practice in Saudi Arabia. Conference on corporate governance held at Birmingham University Business School.

Haji-Abdullah, N. M., \& Wan-Hussin, W. N. (2015). Related party transactions, audit committees and real earnings management: The moderating impact of family ownership. Advanced Science Letters, 21(6), 2033-2037.

Hamid, F., Hashim, H. A., \& Salleh, Z. (2012, December). Motivation for earnings management among auditors in Malaysia. Procedia - Social and Behavioral Sciences, 65, 239-246.

Hasnan, S., Abdul-Rahman, R., \& Mahenthiran, S. (2013). Management motive, weak governance, earnings management, and fraudulent financial reporting: Malaysian evidence. Journal of International Accounting Research, 12(1), 1-27. https://doi.org/10.2308/jiar-50353

Hassan, M.-H., Moyes, G. D., Mohd-Sanusi, Z., \& Iskandar, T. M. (2010). The enforcement role of the companies commission of Malaysia. International Business \& Economics Research Journal (IBER), 9(2), 135-148. 
Healy, P. M. (1985). The effect of bonus schemes on accounting decisions. Journal of Accounting and Economics, 7(1), 85-107. https://doi.org/10.1016/0165-4101(85)90029-1

Hillman, A. J., Cannella, A. A., \& Paetzold, R. L. (2000). The resource dependence role of corporate directors: Strategic adaptation of board composition in response to environmental change. Journal of Management Studies, 37(2), 235-256. https://doi.org/10.1111/1467-6486.00179

Inaam, Z., \& Khamoussi, H. (2016). Audit committee effectiveness, audit quality and earnings management: a meta-analysis. International Journal of Law and Management, 58(2), 179-196.

Ishak, I., Haron, M. N., Salleh, N., \& Rashid, A. A. (2011). Family control and earnings management: Malaysia evidence. Paper presented at the 2nd International Conference on Economics, Business and Management IPEDR, 22@IACSIT Press, Singapore.

Jamaludin, N. D., Sanusi, Z. M., \& Kamaluddin, A. (2015). Board structure and earnings management in Malaysian government linked companies. Procedia Economics and Finance, 28, 235-242.

Jensen, M. C., \& Meckling, W. H. (1976). Theory of the firm: Managerial behavior, agency costs and ownership structure. Journal of Financial Economics, 3(4), 305-360. https://doi.org/10.1016/0304-405X(76)90026-X

Jones, K., Krishnan, G. V., \& Melendrez, K. (2008). Do models of discretionary accruals detect actual cases of fraudulent and restated earnings? An empirical analysis. Contemporary Accounting Research, 25(2), $499-531$.

Jones, M. (2011). Creative accounting, fraud and international accounting scandals. England: John Wiley \& Sons.

Kalgo, S. H., Noordin, B. A. A., Nahar, H. S. B., \& Turmin, S. Z. B. (2015). The impact of institutional investors on real and accrual earnings management around IPO: Evidence from Malaysian Emerging Market. Capital Markets Review, 23(1/2), 65-83.

Kazemian, S., \& Sanusi, Z. M. (2015). Earnings management and ownership Structure. Procedia Economics and Finance, 31, 618-624. https://doi.org/10.1016/S2212-5671(15)01149-1

Khoo, C.-P., \& Ahmad-Zaluki, N. A. (2015). IFRS convergence and earnings management. Pertanika Journal of Social Sciences \& Humanities, 23(5), 75-84.

Kim, J.-B., \& Sohn, B. C. (2013). Real earnings management and cost of capital. Journal of Accounting and Public Policy, 32(6), 518-543. https://doi.org/10.1016/j.jaccpubpol.2013.08.002

Klein, A. (2002). Audit committee, board of director characteristics, and earnings management. Journal of Accounting and Economics, 33(3), 375-400. https://doi.org/10.1016/S0165-4101(02)00059-9

Kline, R. B. (2015). Principles and practice of structural equation modeling (4rd ed.). New York, London: Guilford publications.

Ku Ismail, K. N. I., \& Abdullah, S. N. (2013). Does women representation on boards and audit committees restrict earnings management? The impact of family ownership in Malaysian firms. Paper presented at the Proceedings of the $1^{\text {st }}$ AARESOC International Conference on Business and Management (AARESOC-ICBM 2013), Izmir, Turkey.

Kwon, S. Y., Na, K., \& Park, J. (2017). The economic effects of IFRS adoption in Korea. Asia-Pacific Journal of Accounting \& Economics, 1-41.

Lemma, T. T., Negash, M., Mlilo, M., \& Lulseged, A. (2018, September). Institutional ownership, product market competition, and earnings management: Some evidence from international data. Journal of Business Research, 90, 151-163. https://doi.org/10.1016/j.jbusres.2018.04.035

Lisboa, I. (2016). Impact of financial crisis and family control on earning management of Portuguese listed firms. European Journal of Family Business, 6(2), 118-131. https://doi.org/10.1016/j.ejfb.2017.06.002

Liu, J.-L., \& Tsai, C.-C. (2015). Board member characteristics and ownership structure impacts on real earnings management: Evidence from Taiwan. Accounting and Finance Research, 4(4), 84-96.

Liu, M., Shi, Y., Wilson, C., \& Wu, Z. (2017, June). Does family involvement explain why corporate social responsibility affects earnings management?. Journal of Business Research, 75, 8-16.

Liu, Z.-J., \& Wang, Y.-S. (2017). Effect of earnings management on economic value added: G20 and African countries study. South African Journal of Economic and Management Sciences, 20(1), 1-9.

Lückerath-Rovers, M. (2009, June). Female directors on corporate boards provide legitimacy to a company: A resource dependency perspective. Management Online Review, 1-13. Retrieved from https://ssrn.com/abstract=1411693 
Luo, J.-H., Wan, D.-F., Cai, D., \& Liu, H. (2013). Multiple large shareholder structure and governance: The role of shareholder numbers, contest for control, and formal institutions in Chinese family firms. Management and Organization Review, 9(2), 265-294. https://doi.org/10.1111/more.12000

Mak, Y. (2007). Whistleblowing: Recent Developments and Implementation Issues. Retrieved 19 January 2019, from http://agris.fao.org/agris-search/search.do?recordID=US2012413910

Mansor, N., Che-Ahmad, A., Ahmad-Zaluki, N., \& Osman, A. (2013). Corporate governance and earnings management: A study on the Malaysian family and non-family owned PLCs. Procedia Economics and Finance, 7 , 221-229. https://doi.org/10.1016/S2212-5671(13)00238-4

Martínez-Ferrero, J., Rodríguez-Ariza, L., \& García-Sánchez, I.-M. (2016, November). Corporate social responsibility as an entrenchment strategy, with a focus on the implications of family ownership. Journal of Cleaner Production, 135, 760-770. https://doi.org/10.1016/j.jclepro.2016.06.133

Meng, T. P., \& Fook, O. S. (2011). Comparative analysis of whistleblower protection legislations in England, USA and Malaysia. African Journal of Business Management, 5(27), 11246-11255. https://doi.org/10.5897/AJBM11.1332

Mohammad, W. M. W., Wasiuzzaman, S., \& Salleh, N. M. Z. N. (2016). Board and audit committee effectiveness, ethnic diversification and earnings management: a study of the Malaysian manufacturing sector. Corporate Governance, 16(4), 726-746. https://doi.org/10.1108/CG-06-2015-0085

Mohd Saleh, N., Mohd Iskandar, T., \& Rahmat, M. M. (2005). Avoidance of reported earnings decreases and losses: Evidence from Malaysia. Malaysian Accounting Review, 4(1), 25-37.

Nam, S.-W., \& Nam, I. C. (2004). Corporate governance in Asia: Recent evidence from Indonesia, Republic of Korea, Malaysia, and Thailand. Working Paper, Asian Development Bank Institute.

Nia, M. S., Huang, C. C., \& Abidin, Z. Z. (2015). A review of motives and techniques and their consequences in earnings management. Malaysian Accounting Review, 14(2), 1-28.

Nia, M. S., Sinnadurai, P., Sanusi, Z. M., \& Hermawan, A. (2017, October). How efficient ownership structure monitors income manipulation? Evidence of real earnings management among Malaysian firms. Research in International Business and Finance, 41, 54-66. https://doi.org/10.1016/j.ribaf.2017.04.013

Ow-Yong, K., \& Kooi-Guan, C. (2000). Corporate governance codes: A comparison between Malaysia and the UK. Corporate Governance: An International Review, 8(2), 125-132. https://doi.org/10.1111/1467-8683.00190

Ozili, P. K. (2019). Bank income smoothing, institutions and corruption. Research in International Business and Finance, 49, 82-99. https://doi.org/10.1016/j.ribaf.2019.02.009

Ozili, P. K., \& Outa, E. (2017). Bank loan loss provisions research: A review. Borsa Istanbul Review, 17(3), 144-163.

Packin, N. G., \& Edwards, B. P. (2016). Regulating culture: Improving corporate governance with anti-arbitration provisions for whistleblowers. William \& Mary Law Review Online, 58, 41-64.

Perols, J. L., \& Lougee, B. A. (2011). The relation between earnings management and financial statement fraud. Advances in Accounting, 27(1), 39-53. https://doi.org/10.1016/j.adiac.2010.10.004

Podestà, F. (2002). Recent developments in quantitative comparative methodology: The case of pooled time series cross-section analysis. DSS Papers SOC 3-02. McDonough School of Business, Georgetown University, Washington, DC.

Prommin, P., Jumreornvong, S., Jiraporn, P., \& Tong, S. (2016, November). Liquidity, ownership concentration, corporate governance, and firm value: Evidence from Thailand. Global Finance Journal, 31, 73-87.

Rachagan, S., \& Kuppusamy, K. (2013). Encouraging whistle blowing to improve corporate governance? A Malaysian initiative. Journal of Business Ethics, 115(2), 367-382. https://doi.org/10.1007/s10551-012-1402-7

Razzaque, R. M. R., Ali, M. J., \& Mather, P. R. (2016, December). Real earnings management in family firms: Evidence from an emerging economy. Pacific-Basin Finance Journal, 40(Part B), 237-250.

Roychowdhury, S. (2006). Earnings management through real activities manipulation. Journal of Accounting and Economics, 42(3), 335-370. https://doi.org/10.1016/j.jacceco.2006.01.002

Sakawa, H., \& Watanabel, N. (2017). Parent control and ownership monitoring in publicly listed subsidiaries in Japan. Research in International Business and Finance, 45, 7-14. https://doi.org/10.1016/j.ribaf.2017.07.127

Sakawa, H., \& Watanabel, N. (2018). Family control and ownership monitoring in Stakeholder-oriented corporate governance. Management Decision. https://doi.org/10.1108/MD-04-2018-0480 
Salancik, G. R., \& Pfeffer, J. (1978). The external control of organizations: A resource dependence perspective. New York: Harper \& Rovo.

Saleh, N. M., Iskandar, T. M., \& Rahmat, M. M. (2005). Earnings management and board characteristics: Evidence from Malaysia. Jurnal Pengurusan, 24(4), 77-103. https://doi.org/10.17576/pengurusan-2005-24-04

Salleh, N. M. Z. N., \& Haat, M. H. C. (2013). Audit committee diversity-Malaysian evidence after the revision of MCCG. Malaysian Accounting Review, 12(2), 91-113.

Schultz, D., \& Harutyunyan, K. (2015). Combating corruption: The development of whistleblowing laws in the United States, Europe, and Armenia. International Comparative Jurisprudence, 1(2), 87-97.

Shawver, T. J., \& Clements, L. H. (2006). The intention of accounting students to whistleblow in situations of questionable ethical dilemmas. Research on Professional Responsibility and Ethics in Accounting, 11(1), 177-191. https://doi.org/10.1016/S1574-0765(06)11009-2

Shawver, T. J., \& Shawver, T. A. (2007). Will corporate governance and whistleblowing provisions improve financial responsibility?. Research on Professional Responsibility and Ethics in Accounting, 12, 123-148.

Soliman, M. M., \& Ragab, A. A. (2014). Audit committee effectiveness, audit quality and earnings management: an empirical study of the listed companies in Egypt. Research Journal of Finance and Accounting, 5(2), 155-166.

StataCorp. (2015). Stata longitudinal-data/panel-data reference manual: Release 14. College Station, Texas: StataCorp LP.

Sulaiman, S., Danbatta, B. L., \& Rahman, R. A. (2014, August). Figure massaging practices in Malaysian firms: Are they fraudulent?. Procedia-Social and Behavioral Sciences, 145, 29-39.

Sun, J., Lan, G., \& Liu, G. (2014). Independent audit committee characteristics and real earnings management. Managerial Auditing Journal, 29(2), 153-172. https://doi.org/10.1108/MAJ-05-2013-0865

Teh, B. H., San Ong, T., \& Ying, L. Y. (2017). Earnings management in Malaysian public listed family firms. Jurnal Pengurusan (UKM Journal of Management), 51. https://doi.org/10.17576/pengurusan-2017-51-16

Tsao, S.-M., Lin, C.-H., \& Chen, V. Y. (2015). Family ownership as a moderator between R\&D investments and CEO compensation. Journal of Business Research, 68(3), 599-606. https://doi.org/10.1016/j.jbusres.2014.09.001

Vladu, A. B. (2015). Managerial preferences between accrual-based versus real earnings management. Hyperion International Journal of Econophysics \& New Economy, 8(2), 237-245.

Wan Ismail, W. A., Kamarudin, K. A., Zijl, T. V., \& Dunstan, K. (2013). Earnings quality and the adoption of IFRS-based accounting standards: Evidence from an emerging market. Asian Review of Accounting, 21(1), 53-73.

Wooldridge, J. M. (2010). Econometric analysis of cross section and panel data. MIT Press, Cambridge, Massachusetts. London, England.

Xie, B., Davidson, W. N., \& DaDalt, P. J. (2003). Earnings management and corporate governance: the role of the board and the audit committee. Journal of Corporate Finance, 9(3), 295-316.

Xu, G., \& Ji, X. (2016). Earnings management by top Chinese listed firms in response to the global financial crisis. International Journal of Accounting and Information Management, 24(3), 226-251.

Yang, J. S., \& Krishnan, J. (2005). Audit committees and quarterly earnings management. International Journal of Auditing, 9(3), 201-219. https://doi.org/10.1111/j.1099-1123.2005.00278.x

Yoshikawa, T., \& Rasheed, A. A. (2010). Family control and ownership monitoring in family-controlled firms in Japan. Journal of Management Studies, 47(2), 274-295. https://doi.org/10.1111/j.1467-6486.2009.00891.x

Yuliana, R., Anshori, M., \& Alim, M. N. (2015, November). Real earnings management in the Indonesian sharia capital market. Procedia-Social and Behavioral Sciences, 211, 866-873.

Zain, M. M., Subramaniam, N., \& Stewart, J. (2006). Internal auditors' assessment of their contribution to financial statement audits: The relation with audit committee and internal audit function characteristics. International Journal of Auditing, 10(1), 1-18. https://doi.org/10.1111/j.1099-1123.2006.00306.x

Zainal Abidin, N. A., \& Ahmad, H. (2007). Corporate governance in Malaysia: The effect of corporate reforms and state business relation in Malaysia. Asian Academy of Management Journal, 12(1), 23-34.

Zalata, A. M., Tauringana, V., \& Tingbani, I. (2018). Audit committee financial expertise, gender, and earnings management: Does gender of the financial expert matter?. International Review of Financial Analysis, 55, 170-183. https://doi.org/10.1016/j.irfa.2017.11.002 